\title{
Implementasi Augmented Reality warisan Budaya Berwujud di Museum Propinsi Sulawesi Utara
}

\author{
Auliawati Buchari, Steven R. Sentinuwo, Stanley D.S Karouw. \\ Teknik Informatika Universitas Sam Ratulangi, Manado Indonesia \\ Email: liabuchari@gmail.com, stanleydsk@me.com, steven@unsrat.ac.id
}

\begin{abstract}
Abstrak --- Kebutuhan teknologi berkembang seiring dengan perkembangan zaman. Bermacam teknologi telah diciptakan untuk berbagai macam keperluan, terutama didalam bidang informasi. Salah satu bentuk teknologi yang berkembang adalah Augmentet Reality (AR). Penelitian ini bertujuan untuk menerapkan teknologi Augmeneted Reality pada warisan budaya berwujud di Museum Propinsi Sulawesi Utara. Augmented Reality merupakan teknologi yang menggabungkan benda maya dua dimensi atau tiga dimensi ke dalam lingkungan nyata secara real time. Aplikasi Augmented Reality warisan budaya berwujud di Museum Propinsi Sulawesi Utara ini dibuat dengan menggunakan aplikasi Layar. Metode yang digunakan sebagai tahapan penelitian adalah metodologi Rapid Application Development (RAD) yang merupakan metode proses perangkat lunak yang menekan pada daur pengembangan hidup yang singkat. Cara kerja aplikasi ini yaitu kamera difungsikan sebagai alat input yang akan menangkap marker atau markeless. Hasil yang diperoleh merupakan suatu informasi yang dapat digunakan sebagai referensi atau pengetahuan terhadap warisan budaya berwujud.
\end{abstract}

Kata Kunci : Augmented Reality, Warisan Budaya, Rapid Application Development, Marker, Markeless.

\section{PENDAHULUAN}

Perkembangan TI pada dunia mempunyai tingkat pertumbuhan yang sangat besar. Terutama pada bidang smartphone. Smartphone di Indonesia saat ini mulai tersedia dengan harga yang semakin terjangkau. Hal ini membuat membuat jumlah pengguna smartphone di Indonesia bertambah banyak.

Salah satu OS pada smartphone yang sedang berkembang dengan pesat adalah Android. Seiring dengan perkembangan smartphone yang begitu pesat maka banyak mereka yang membuat aplikasi-aplikasi menjadi lebih menarik, salah satunya aplikasi menggunakan $A R$. Masyarakat umum saat ini masih banyak yang belum mengenal apa itu $A R$. Augmented Reality (AR) merupakan integrasi elemen digital yang ditambahkan ke dalam dunia nyata secara waktu nyata dan mengikuti keadaan lingkungan yang ada didunia nyata serta dapat diterapkan pada perangkat mobile.

Warisan budaya dibagi menjadi dua kategori : warisan budaya berwujud dan tidak berwujud. Warisan budaya berwujud dibagi menjadi warisan tidak bergerak dan warisan bergerak. Warisan tidak bergerak termasuk bangunan bersejarah, monumen, situs arkeologi. Warisan bergerak meliputi lukisan, patung, furniture, lukisan dinding. Warisan budaya tak benda terdiri dari tradisi lisan dan ekspresi, termasuk bahasa,seni pertunjukan, kebiasaan sosial, ritual, festival, ilmu pengetahuan dan kebiasaan yang berhubungan dengan alam dan dunia, dan keterampilan tradisional. [1]
Museum Propinsi Sulawesi Utara merupakan media informasi tentang sejarah alam, manusia dan budaya Sulawesi Utara. Museum ini terpilih sebagai salah satu museum yang mendapatkan program 'Revitalisasi Museum' pada tahun 2011 dari pemerintah pusat. Museum Sulawesi Utara dibangun untuk mendokumentasikan segala hal yang berkaitan dengan sejarah alam, manusia dan kebudayaan di wilayah Propinsi Sulawesi Utara.

Penggunaan teknologi Augmented Reality dalam pengembangan aplikasi, dimaksud sebagai upaya pelestarian budaya berwujud. Selain itu juga, menambah daya tarik generasi muda terhadap warisan - warisan budaya, seperti yang terdapat pada Museum Propinsi Su lawesi Utara.

\section{LANDASAN TEORI}

\section{A. Warisan Budaya}

Menurut UNESCO warisan budaya dibagi menjadi dua kategori, yaitu warisan budaya berwujud dan tidak berwujud. Warisan budaya berwujud dibagi menjadi warisan tidak bergerak dan warisan bergerak. Warisan tidak bergerak termasuk bangunan bersejarah, monumen, situs arkeologi. Warisan bergerak meliputi lukisan, patung, furniture, lukisan dinding. Warisan budaya takbenda terdiri dari tradisi lisan dan ekspresi, termasuk bahasa,seni pertunjukan, kebiasaan sosial, ritual, festival, ilmu pengetahuan dan kebiasaan yang berhubungan dengan alam dan dunia, dan keterampilan tradisional [1]

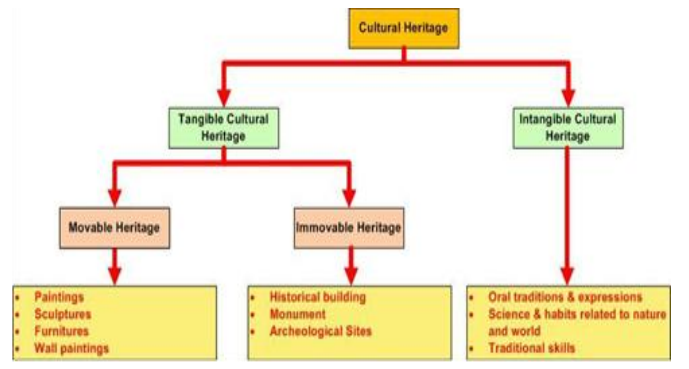

Gambar 1 Klasifikasi Warisan Budaya dari UNESCO [1]

\section{B. Teknologi Augmented Reality}

Augmented Reality (AR) merupakan kombinasi antara dunia maya (virtual) dan dunia nyata (Real) yang dibuat oleh komputer. Objek virtual dapat berupa teks, animasi, model 3D atau video yang digabungkan dengan lingkungan, sebenarnya sehingga pengguna merasakan obyek virtual berada dilingkungannya. Tidak seperti realitas maya (virtual reality) yang sepenuhnya menggantikan kenyataan, realitas tertambah sekedar menambahkan atau melengkapi kenyataan. Augmented Reality merupakan upaya untuk menggabungkan dunia nyata dan dunia virtual yang dibuat 
melalui komputer sehingga batas antara keduanya menjadi sangat tipis. Unsur penambahan realitas suatu objek diutamakan pada teknologi ini. [2]

Dalam konteks yang lebih umum, AR juga disebut Mixed Reality (MR), mengacu pada Virtual Reality (VR), Augmented Reality (AR), dan teknologi terkait lainnya.

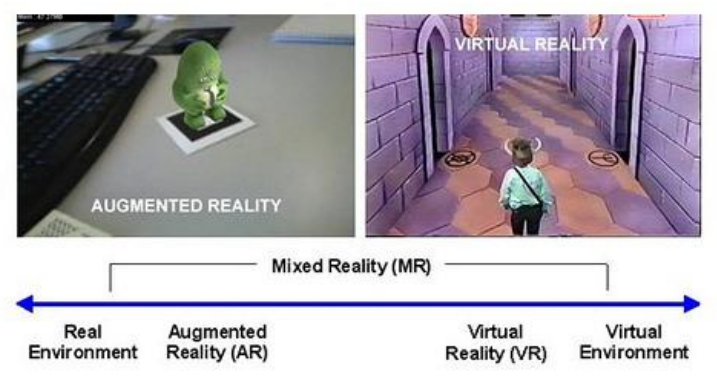

Gambar 2 Mixed Reality

Benda-benda maya menampilkan informasi yang tidak dapat diterima oleh pengguna dengan inderanya sendiri. Hal ini membuat augmented reality sesuai sebagai alat untuk me mbantu persepsi dan interaksi penggunanya dengan dunia nyata. Informasi yang ditampilkan oleh benda maya membantu pengguna melaksanakan kegiatan dalam dunia nyata Salah satu fitur utama dari Augmented Reality adalah media interaktif. [3]

\section{Layar}

Layar merupakan sebuah platform yang mendukung pengembangan Augmented Reality. Perusahaannya sudah ada sejak Juni 2009 dan berbasis di A msterdam.

Layar adalah aplikasi Augmented Reality yang paling banyak digunakan pada saat ini yang dapat digunakan pada smartphone Android dan iPhone. Layar menunjukkan apa yang ada di sekitar degnan menampilkan informasi di atas dunia nyata seperti yang terlihat lewat kamera smartphone. Lapisan konten yang berjalan di aplikasi Layar disebut layer. Layar juga menyediakan platform yang terbuka sehingga memungkin kan para pengembang untuk membuat layer sendiri. Dengan Layar kita bisa menjelajahi kontenkonten digital seperti video atau audio pada majalah, katalog, selebaran, brosur, kartu nama, dan benda lainnya dan membagikannya di akun media social milik kita. Saat ini, ketika menggunakan Layar untuk pengembangan Augmented Reality, kita bisa terintegrasi dengan Youtube, Twitter, Facebook, Google+, Pinterest, dan LinkedIn. Bahkan kita bisa melihat informasi dari daerah yang kita datangi dengan memindai tempat tersebut menggunakan browser Layar.

Layar memberikan kesempatan pengguna untuk mengembangkan bisnis, meningkatkan penjualan dan pelanggan, meraih rating yang lebih tinggi dan menambah nilai lebih dari usaha atau promosi yang dijalankan.

Sampai pada Agustus 2013 penggunaan Layar terus bertumbuh sampai dengan rata-rata 1 juta pengunduhan setiap bulannya. Sudah terdapat lebih dari 40.000 kampanye interaktif yang menunjukkan Layar telah berkembang pesat di seluruh dunia. [4]

\section{Marker}

Tahap pertama dalam membangun Augmented Reality adalah dengan mengenal Marker. Marker merupakan sebuah gambar berpola khusus yang sudah dikenali oleh Template
Memory ARToolKit. Nantinya, marker tersebut berfungsi untuk dibaca dan dikenali oleh kamera lalu dicocokkan dengan template.

Setelah itu, baru kamera akan melakukan render objek 3D diatas marker. Marker standar yang sering dipakai oleh para user pemula Augmented Reality adalah Marker Hiro dan Marker Kanji. Kedua pola Marker tersebut sudah ada pada Template Memory ARToolKit, jadi user pemula dapat mengembangkan Augmented Reality lebih jauh lagi. [5]

\section{E. Markerless}

Salah satu metode Augmented Reality yang saat ini sedang berkembang adalah metode Markerless Augmented Reality. Dengan metode ini pengguna tidak perlu lagi menggunakan sebuah marker yang berbentuk kotak dan berwarna hitam putih untuk menampilkan elemen-elemen digital. Seperti yang saat ini dike mbangkan oleh perusahaan Augmented Reality terbesar di dunia Total Immersion, mereka telah membuat berbagai macam teknik Markerless Tracking sebagai teknologi andalan mereka, seperti Face Tracking, 3D Object Tracking, dan Motion Tracking. [2]

1. Face Tracking

Dengan menggunakan alogaritma yang mereka kembangkan, komputer dapat mengenali wajah manusia secara umum dengan cara mengenali posisi mata, hidung, dan mulut manusia, kemudian akan mengabaikan objek-objek lain di sekitarnya seperti pohon, rumah, dan benda-benda lainnya.

2. 3 D Object Tracking

3D Object Tracking dapat mengenali semua bentuk benda yang ada disekitar, seperti mobil, meja, televisi, dan lain-lain.

3. Motion Tracking

Pada teknik ini komputer dapat menangkap gerakan. Motion Tracking telah mulai digunakan secara ekstensif untuk memproduksi film-film yang mencoba mensimu lasikan gerakan. Contohnya pada film Avatar, di mana James Cameron menggunakan teknik ini untuk membuat film tersebut dan menggunakannya secara realtime.

\section{GPS Based Tracking}

Teknik GPS Based Tracking saat ini mulai populer dan banyak dikembangkan pada aplikasi s martphone (iPhone dan Android). Dengan memanfaatkan fitur GPS dan kompas yang ada didalam smartphone, aplikasi akan mengambil data dari GPS dan kompas kemudian menampilkannya dalam bentuk arah yang kita inginkan secara realtime, bahkan ada beberapa aplikasi menampikannya dalam bentuk 3D. [2]

\section{F. Pengolahan Citra}

Citra merupakan istilah lain untuk gambar. Secara harafiah, citra adalah gambar pada bidang dua dimensi. Citra adalah salah satu komponen multimedia yang me megang peranan penting sebagai bentuk ko munikasi visual. Citra adalah suatu representasi, kemiripan, atau imitasi dari suatu objek. Citra mempunyai karakteristik yang tidak dimiliki oleh data teks, yaitu citra karya dengan informasi. [6]

\section{G. Metodologi Rapid Application Development (RAD)}


Rapid Application Development (RAD) adalah suatu pendekatan berorientasi objek terhadap pengembangan sistem yang mencangkup suatu metode pengembangan serta perangkat-perangkat lunak. RAD bertujuan mempersingkat waktu yang biasanya diperlukan dalam siklus hidup pengembangan sistem tradisional antara perancangan dan penerapan suatu sistem informasi. Pada akhirnya, RAD sama-sama berusaha memenuhi syarat-syarat bisnis yang berubah secara cepat.

Terdapat tiga fase dalam RAD yang melibatkan penganalisis dan pengguna dalam tahap penilaian, perancangan, dan penerapan. Adapun ketiga fase tersebut adalah requirements planning (perancangan persyaratan), RAD design workshop (workshop desain RAD), dan implementation (Implementasi). [7]

\section{METODE PENELITIAN}

Prosedur penelitian merupakan kerangka kerja yang digunakan dalam melaksanakan penelitian. Prosedur penelitian yang diadaptasi dari fase pendekatan Rapid Aplication Development (RAD) adalah sebagai berikut.

\section{A. Fase Analisis Persyaratan}

Fase ini bertujuan untuk mengidentifikasi layanan, batasan dan obyektifitas dari sistem dari pengumpulan data yang telah dilakukan. Fase ini terdiri dari 4 aktifitas utama, yaitu :

1. Ko munikasi dan Perencanaan Proyek

Langkah komunikasi dan perancangan proyek adalah untuk mengidentifikasi kegiatan, patokan dan apa yang dihasilkan oleh proyek. Aktifitas yang dilakukan yaitu melakukan wawancara pada petugas pihak Museum Propinsi Sulawesi Utara. Wawancara dilakukan untuk mendapatkan informasi - informasi Museum serta objek - objek yang terdapat didalamnya yang akan dijadikan kebutuhan dari pengembangan aplikasi yang akan di bangun.

Setelah melaksanakan langkah komunikasi dengan wawancara selanjutnya dilakukan sebuah perencanaan yang terkait dengan perancangan aplikasi.

\section{Pengumpulan Data}

Pengumpulan data adaalah data yang diperoleh dari penelitian, disini penulis melakukan metode pengumpulan data secara observasi, pencatatan sistematis pada objek yang diperlukan. Materi / bahan yang dikumpulkan.

\section{Studi Kelayakan}

Pada studi kelayakan dilakukan kelayakan teknis dan kelayakan jadwal. Kelayakan tekn is adalah ukuran kepraktisan solusi teknis tertentu atau ketersediaan sumber dan pakar teknis yang digunakan untuk menetukan penggunaan solusi teknis tertentu dalam aplikasi dan ketersediaan sumber daya dan keahlian teknis. Aspek kelayakan teknis mempertimbangkan masalah pokok.

\section{Spesifikasi Pengguna}

Spesifikasi pengguna yaitu untuk mengidentifikasi dan menetapkan user mengenai apa yang akan dicapai.
Spesifikasi pengguna ini akan menghasilkan daftar pengguna.

Dari wawancara yang dilakukan, didapatkan hasil analisa tentang para pengguna yang nantinya akan menggunakan aplikasi augmented reality berbasis mobile. Daftar pengguna sistem berisikan aktor - aktor yang akan menggunakan aplikasi serta hak akses sesuai perannya.

\section{B. Fase RAD Design Workshop (Pemodelan)}

Tujuan fase ini untuk menganalisis semua kegiatan dalam arsitektur sistem secara keseluruhan. Tujuan lainnya yaitu untuk meningkatkan pemahaman terhadap permasalahan yang selanjutnya dilakukan perancang sistem berdasarkan analisis yang telah dilaku kan .

Pada analisa proses dan kinerja sistem memperoleh deskripsi secara jelas yang menjadi kebutuhan terhadap sistem yang dikembangkan dengan menggunakan model diagram use case. Berikut adalah diagram use case beserta deskripsinya:

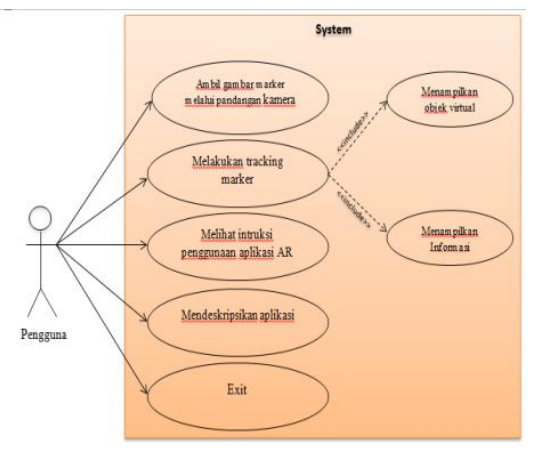

Gambar 3 Use case Diagram Pengguna

Pada use case diagram ini menggambarkan tentang interaksi antara pengguna dan sistem augmented reality. Disini digambarkan pengguna melakukan beberapa kegiatan seperti pengambilan gambar pada marker atau markeless dan melakukan proses tracking sehingga akan tampil instruksi pengguna aplikasi augmented reality.

Hasil dari langkah ini dituangkan dalam storyboard yang desain Interface pada aplikasi augmented reality berbasis mobile ini terdiri dari pengambilan halaman awal, home, search. Rancangan dapat digambarkan seperti pada gambar berikut :

\section{Halaman Awal}

Gambar 1 merupakan tampilan halaman awal dari aplikasi ini. Pada tampilan halaman ini, terdapat title Layar dari aplikasi, dengan sebuah gambar yang menjadi latar be lakang aplikasi.

\section{Home}

Tampilan Home ini berisi title Layar dari aplikasi, serta beberapa menu yaitu Scan yang berfungsi untuk menscan gambar pada layar, Go Layers yang berfungsi 
untuk menampilkan pencarian lokasi, serta Recent Content apabila ada konten yang baru.

\section{Search}

Tampilan search merupakan tampilan yang dimana berisis title layar dari aplikasi ini serta berisi garis untuk mencari aplikasi layer yang ingin ditampilkan

\section{Fase Implementasi (Konstruksi)}

Tahap konstruksi adalah tahap untuk menetukan lingkungan implementasi yang bertujuan untuk menfasilitasi pengembangan sistem dengan menggunakan perangkat keras serta perangkat lunak yang sudah ditentukan dan pengembangan yang bertujuan dalam pembuatan multimedia, pembuatan objek gambar dan pengintegrasian objek gambar dengan teknologi augmented reality berdasarkan desain yang telah dibuat.

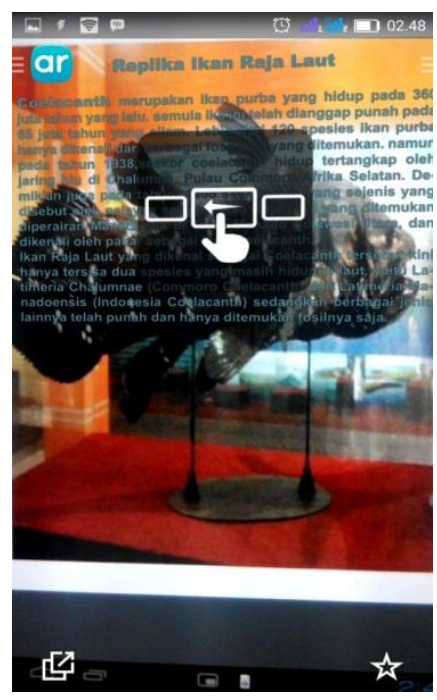

Gambar 4. Tampilan Hasil aplikasi

\section{HASIL DA N PEMBAHASAN}

Tahap menjalankan aplikasi augmented reality warisan budaya berwujud pada Museum Propinsi Sulawesi Utara menggunakan smartphone. Dalam menjalankan aplikasi ini pada smartphone, pengguna harus sudah mempunyai aplikasi Layar pada gadgetnya masing - masing dan terhubung dengan koneksi internet. Berikut adalah langkah - langkah menjalankan aplikasi ini.

\section{A. Halaman Input}

Tampilan input merupakan tampilan untuk mencari layar dimana berisi garis untuk mencari aplikasi layar yang ingin ditampilkan, terlihat pada gambar 5

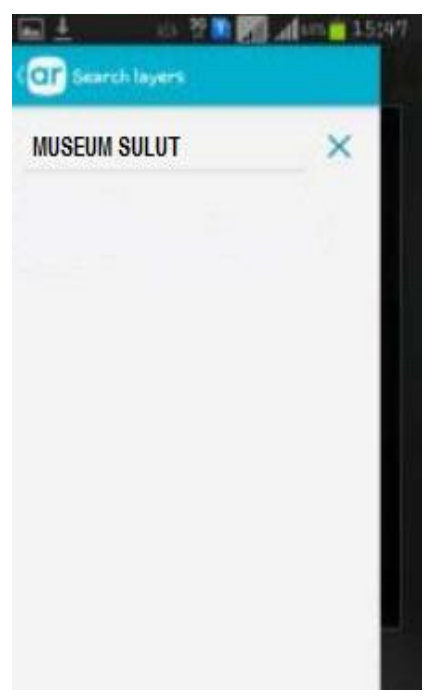

Gambar 5. Halaman Input

\section{B. Halaman Proses}

Setelah tampilan awal akan tampil menu utama dari aplikasi, yaitu tampilan proses dimana berisi title layar dari aplikasi ini serta beberapa menu yaitu scan yang berfungsi menscan gambar pada layar, geo layers berfungsi untuk menampilkan fungsi pencarian tempat, serta recent content apabila ada konten yang baru, terlihat pada gambar 6 .

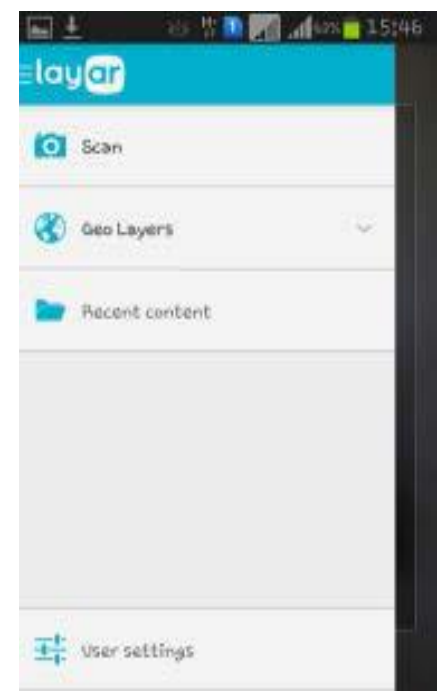

Gambar 6. Halaman Proses

\section{Halaman Output}

Halaman output merupakan tampilan pemindahan konten virtual pada augmented reality yang menghasilkan tampilan output gambar 7. 


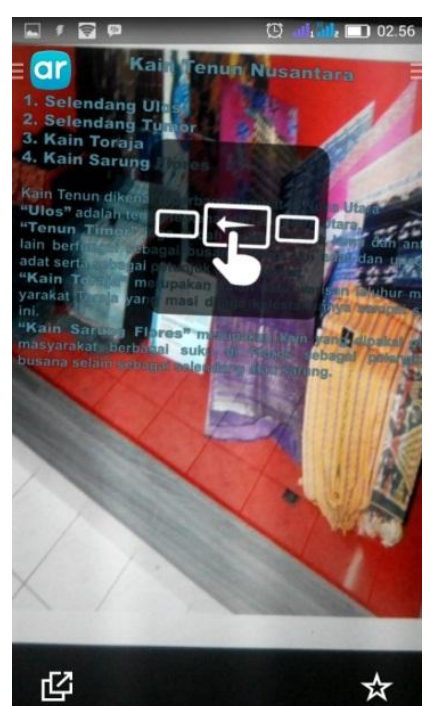

Gambar 7. Halaman Output

Setelah proses menjalankan aplikasi telah selesai, ada beberapa penjelasan dan beberapa tampilan hal yang penting didapatkan.

\section{Koneksi internet}

Dalam pemindaian objek gambar diperlukan internet yang baik dan stabil agar dapat menampilkan konten virtual dengan lancar dan cepat. Dalam tahap pengujian telah di uji, pemindaian menggunakan koneksi internet dengan provider telepon seluler dengan jaringan Edge bisa muncul konten virtual namun tidak selancar dan secepat pemindaian dengan menggunakan jaringan $3 \mathrm{G}$.

\section{Penutupan Konten}

Setelah tahap pemindahan, akan tampak objek virtual yang sesuai dengan konten yang dipindai. Namun ketika objek gambar terhalangi dengan tangan atau benda lain, konten virtual akan menghilang. Tapi setelah benda atau tangan dipindahkan, maka konten virtual akan dapat terlihat kembali tanpa ada proses buffering.

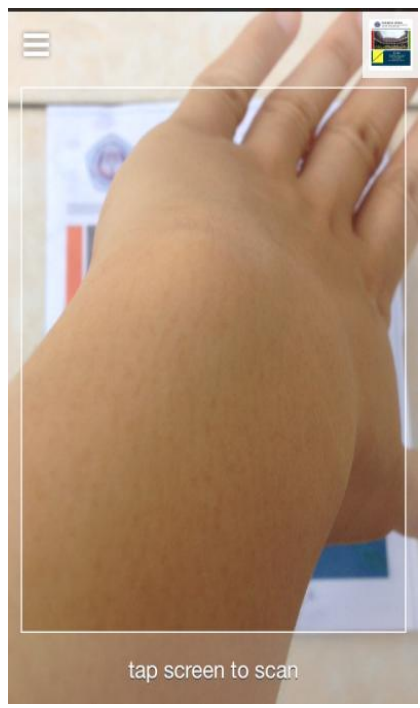

Gambar 8 Penutupan Konten

\section{Cahaya}

Faktor cahaya yang dapat ditangkap oleh lensa kamera juga sangat berperan penting karena dalam tahap pemindaian memerlukan cahaya yang cukup untuk dapat diproses dan dipindai.

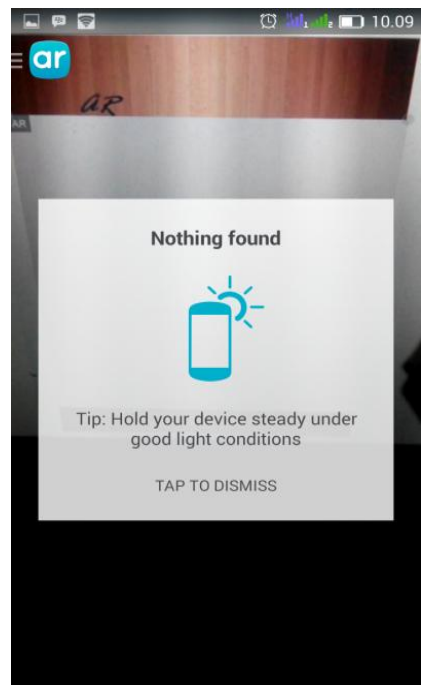

Gambar 9. Faktor Cahaya

4. Jarak

Jarak juga menjadi masalah dalam pemindaian dan pendeteksian konten dalam objek gambar yang telah dibuat. Ketika jarak terlalu jauh, maka pemindaian bisa kurang fokus.

\section{KESIMPULAN}

Berdasarkan tahap-tahap penelitian yang sudah dilakukan dalam menge mbangkan aplikasi Augmented Reality dapat ditarik kesimpulan, yaitu:

1. Dari hasil penelitian, pemindahan konten virtual pada Augmented Reality (AR) harus dilakukan dengan pencahayaan yang cukup agar dapat menampilkan konten virtual yang diinginkan. Oleh karena itu peneliti menggunakan brosur atau buku saku sebagai media penunjang aplikasi.

2. Penelitian menggunakan metodologi Rapid Aplication Development (RAD) karena metodologi RAD adalah sebuah proses perkembangan software yang singkat dan diperlukan dalam siklus hidup pengembangan sistem antara perancang dan penerapan suatu sistem in formasi.

3. Pengimple mentasian Markerless dan Marker Augmented Reality dapat dibuat dengan platform yang mendukung perkembangan AR, seperti Layar.

4. Dari hasil uji coba yang dilakukan maka dapat disimpulkan bahwa aplikasi yang dikembangkan sudah dapat digunakan sesuai fungsinya yang diharapkan dapat menunjang pengetahuan tentang benda-benda bersejarah yang terdapat pada Museum SULUT.

\section{DAFTAR PUSTAKA}

[1.] Kurniawan, Salim (2011). "E-Cultural Heritage and Natural History Framework: An Integreted Approach 
to Digital Preservation”. International Conference on Telecommunication and Aplication vol 5

[2.] Mario Fernando (2013). Aplikasi Android Augmented Reality menggunakan Vuforia SDK dan Unity Buku 2. Solo : Dhika Prihantono

[3.] Putri, Sanjani (2014). “Aplikasi Augmented Reality Wisata Taman Mini Indonesia Indah Berbasis Android”. Konfrensi Nasyonal Sistem Informasi 2014. Universitas Gunadarma

[4.] http://www.layar.com (diakses 28 Desember 2014).

[5.] Lengkey, Debora (2014). "Brosur Fakultas Tekn ik Universitas Sam Ratulangi Manado dengan Teknologi Markerless Augmented Reality". Jurnal Teknik Elektro dan Komputer.

[6.] Fajar, Febriyan (2014). "Mobile Interactive Augmented Reality" Buku 1. Solo : Dhika Prihantono

[7.] Roger S. Pres man, 2012. Rekayas a Perangkat Lunak Pendekatan Praktisi Edisi 7 - Buku 1. Yogyakarta: Andi

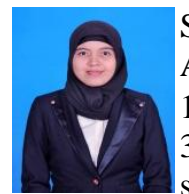

Sekilas dari penulis dengan nama lengkap Auliawati Buchari, lahir pada tanggal 13 April 1993 di kota Manado Sulawesi Utara. Anak ke 3 dari 3 bersaudara dengan memulai pendidikan sekolah dasar d SD Negeri 124

Manado. Kemudian pada tahun 2004 melanjutkan ke Sekolah Menengah Pertama SMP Negri 1 Manado dan pada tahun 2007 melanjutkan ke SMA Negri 9 Manado. Setelah lulus pada tahun 2010 penulis melanjutkan ke Perguruan Tinggi tepatnya di Universitas Sam Ratulangi Manado dengan mengambil jurusan Teknik Informatika. Pada tahun 2014 bulan November penulis membuat skipsi demi memenuhi syarat sarjana (S1) dengan penelitian yang berjudul Implementasi Augmented Reality Warisan Budaya Berwujud di Museum Propinsi Sulawesi Utara yang di bimbing oleh kedua dosen Teknik Informatika Dr. Eng. Steven Sentinuwo, ST., MTI dan Stanley D.S Karouw, ST., MTI sehingga pada tanggal 13 Oktober 2015 penulis resmi lulus di Teknik Informatika Universitas Sam Ratulangi dan menyandang sebagai Sarjana Komputer dengan predikat sangat memuaskan. 